dr Piotr Herbich ${ }^{1}$

\title{
OPTYMALIZACJA POBORU WÓD PODZIEMNYCH DO NAWADNIANIA UŻYTKÓW ROLNYCH W OKRESIE SUSZY
}

\author{
https://doi.org/10.18778/8220-655-5.04
}

\begin{abstract}
Streszczenie: Istniejące w obszarach bilansowych kraju wysokie rezerwy dyspozycyjnych zasobów wód podziemnych umożliwiają ich wykorzystanie do nawadniania upraw rolnych podczas długotrwałej suszy hydrologicznej. W oparciu o dane bazy GIS Mapy Hydrogeologicznej Polski (MHP) w skali 1:50 000 ustalono warunki hydrogeologiczne optymalne dla intensywnego poboru wody studniami wierconymi z poziomów wodonośnych. Pobór z pojedynczej studni może pokryć wysokie niedobory wody upraw rolnych w roku skrajnie suchym na powierzchni najczęściej 15-50 ha zaś czas odbudowy retencji sczerpanych zasobów w ujętym poziomie wodonośnym wyniesie w większości przypadków 1-5 lat. Pobór wód podziemnych do nawadniania 10 ha upraw rolnych w 5-leciu obejmującym jeden rok skrajnie suchy oraz dwa lata umiarkowanie suche może być zbilansowany średnim zasilaniem wód podziemnych 50-100 mm/rok na obszarze 10-30 ha.
\end{abstract}

Slowa kluczowe: hydrogeologia, susza, nawodnienia upraw rolnych, pobór wód podziemnych, bilans wodnogospodarczy.

\section{Wprowadzenie}

W warunkach cyklicznie powtarzającej się głębokiej i długotrwałej suszy w sezonie wegetacyjnym, stało się konieczne opracowanie wskazań do racjonalnego i zrównoważonego wykorzystania rezerw dyspozycyjnych zasobów wód podziemnych do okresowych i intensywnych nawodnień, pokrywających niedobory wodne upraw rolniczych i zapobiegających spadkowi plonów. Podstawy prawne dla wykorzystania zasobów wód podziemnych do nawodnień upraw rolnych w warunkach suszy stwarzają m.in. zapisy ustawy z dnia 20 lipca 2017 roku Prawo wodne. Stanowią one, że zarządzanie zasobami wodnymi ma na celu m.in. ograniczenie skutków suszy poprzez zapewnienie wody na potrzeby rolnictwa w ramach przygotowania i wdrożenia planów przeciwdziałania skutkom suszy na obszarach dorzeczy i w regionach wodnych. W sytuacji stanu klęski żywiołowej wywołanej suszą, dopuszczalne jest korzystanie z wód podziemnych w rozmiarze i czasie wynikającym z konieczności zwalczania zagrożenia dla utrzymania niezbędnego poziomu produkcji rolniczej. Opracowane w latach 2010-2017 dla wybranych zlewni warunki korzystania z wód dopuszczały wykorzystanie rezerw zasobów dyspozycyjnych wód podziemnych do nawodnień upraw rolniczych, gdy pobór odpowiednich ilości wód powierzchniowych nie jest ekonomicznie i technicznie uzasadniony.

Ocena możliwości wykorzystania rezerw zasobów dyspozycyjnych wód podziemnych do nawadniania dla pokrycia niedoborów wodnych upraw rolnych w okresie suszy była przedmiotem zadania, wykonanego w ramach działalności Państwowej Służby Hydrogeologicznej w latach 2015-2017 (Herbich i in. 2018, Herbich 2019) pod nadzorem Krajowego Zarządu Gospodarki Wodnej i sfinansowanego ze środków Narodowego Funduszu Ochrony Środowiska

\footnotetext{
${ }^{1}$ Państwowy Instytut Geologiczny, Państwowy Instytut Badawczy, ul. Rakowiecka 4, 00-975 Warszawa, pher@ pgi.gov.pl, ORCID 0000-0002-7453-2136
} 
i Gospodarki Wodnej. Celem tego zadania było wskazanie optymalnych warunków hydrogeologicznych dla poboru wód podziemnych studniami wierconymi do intensywnego nawadniania upraw rolniczych, pokrywającego ich niedobory wodne i zapobiegającego drastycznemu spadkowi plonów w warunkach głębokiej i długotrwałej suszy hydrologicznej w sezonie wegetacyjnym, prowadzonego z zachowaniem zrównoważonego bilansu wodnogospodarczego w cyklu lat kształtujących stabilność stanu retencji systemu wodonośnego.

\section{Dane i założenia wejściowe do obliczeń}

Określenie wysokości poboru wód podziemnych, niezbędnego dla nawadniania upraw rolnych w okresie suszy, zostało przeprowadzone z wykorzystaniem wskaźnika niedoborów wodnych NW ziemniaka późnego (ryc. 1), którego potencjalny obszar uprawiania obejmuje największą część gruntów ornych w kraju, zaś pokrycie wysokiego niedoboru wodnego tych upraw podczas głębokiej suszy (o prawdopodobieństwie $\mathrm{p}=20 \%$ - występującej raz na 5 lat) będzie równoznaczne z pokryciem niedoboru wody innych upraw (Ostrowski i in. 2008).

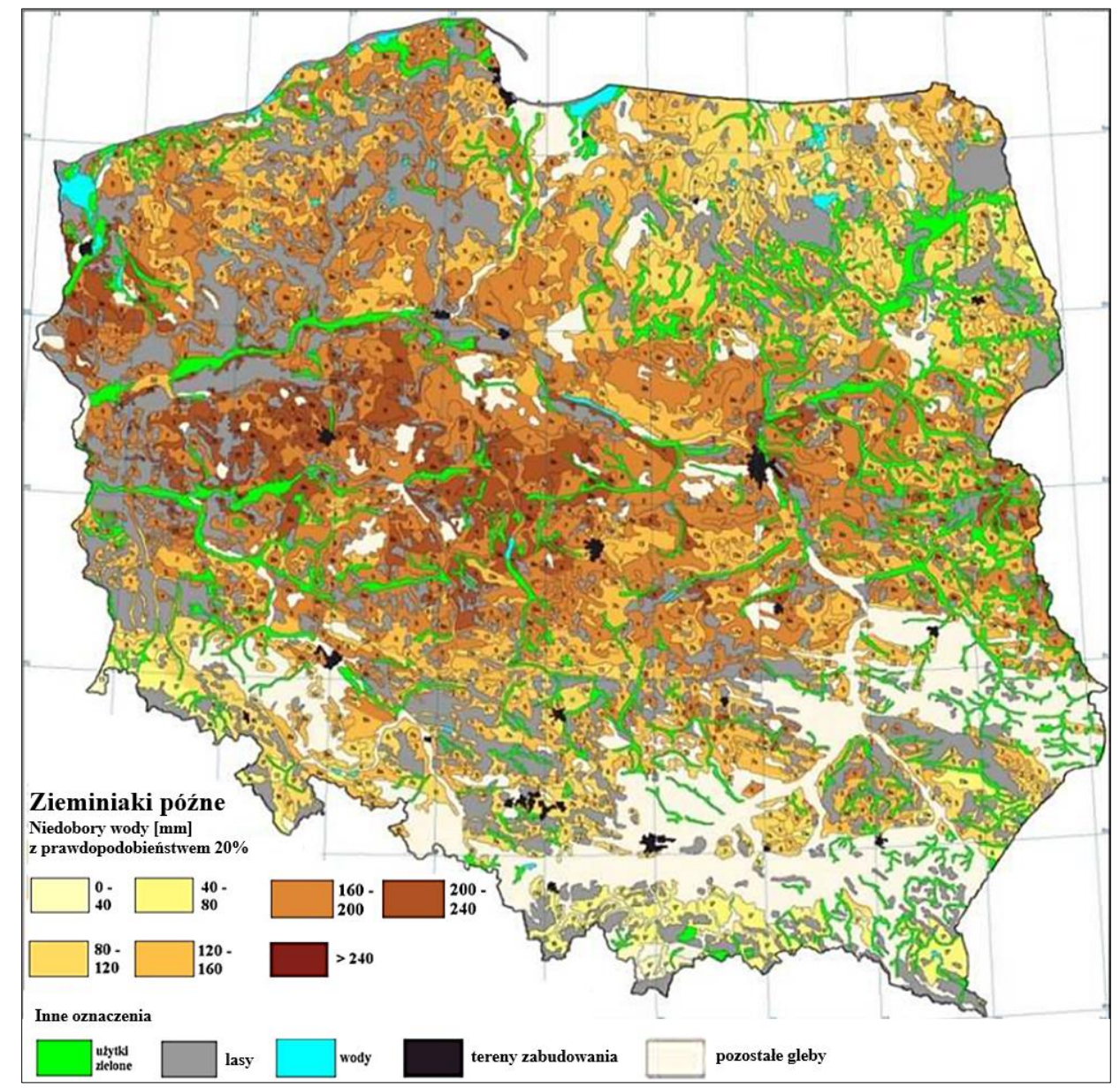

Ryc. 1. Niedobory wodne NW [mm/r] ziemniaka późnego podczas głębokiej suszy rolniczej o prawdopodobieństwie wystąpienia $\mathrm{p}=20 \%$ - raz na pięć lat

Źródło: Instytut Technologiczno-Przyrodniczy - Państwowy Instytut Badawczy w Falentach 
Wysokość możliwych do zagospodarowania rezerw zasobów dyspozycyjnych wód podziemnych jest ustalana corocznie w ramach zadań państwowej służby hydrogeologicznej, a wynikiem tych ustaleń jest m.in. ocena stopnia wzd (wzór 1) wykorzystania zasobów dyspozycyjnych wód podziemnych (ryc. 2):

gdzie:

$$
w z d=\frac{U}{Z D}[\%](1)
$$

$Z D$ - zasoby dyspozycyjne wód podziemnych jednostki bilansowej $\left[\mathrm{m}^{3} / \mathrm{d}\right]$;

$U$ - pobór wód podziemnych w jednostce bilansowej $\left[\mathrm{m}^{3} / \mathrm{d}\right]$.

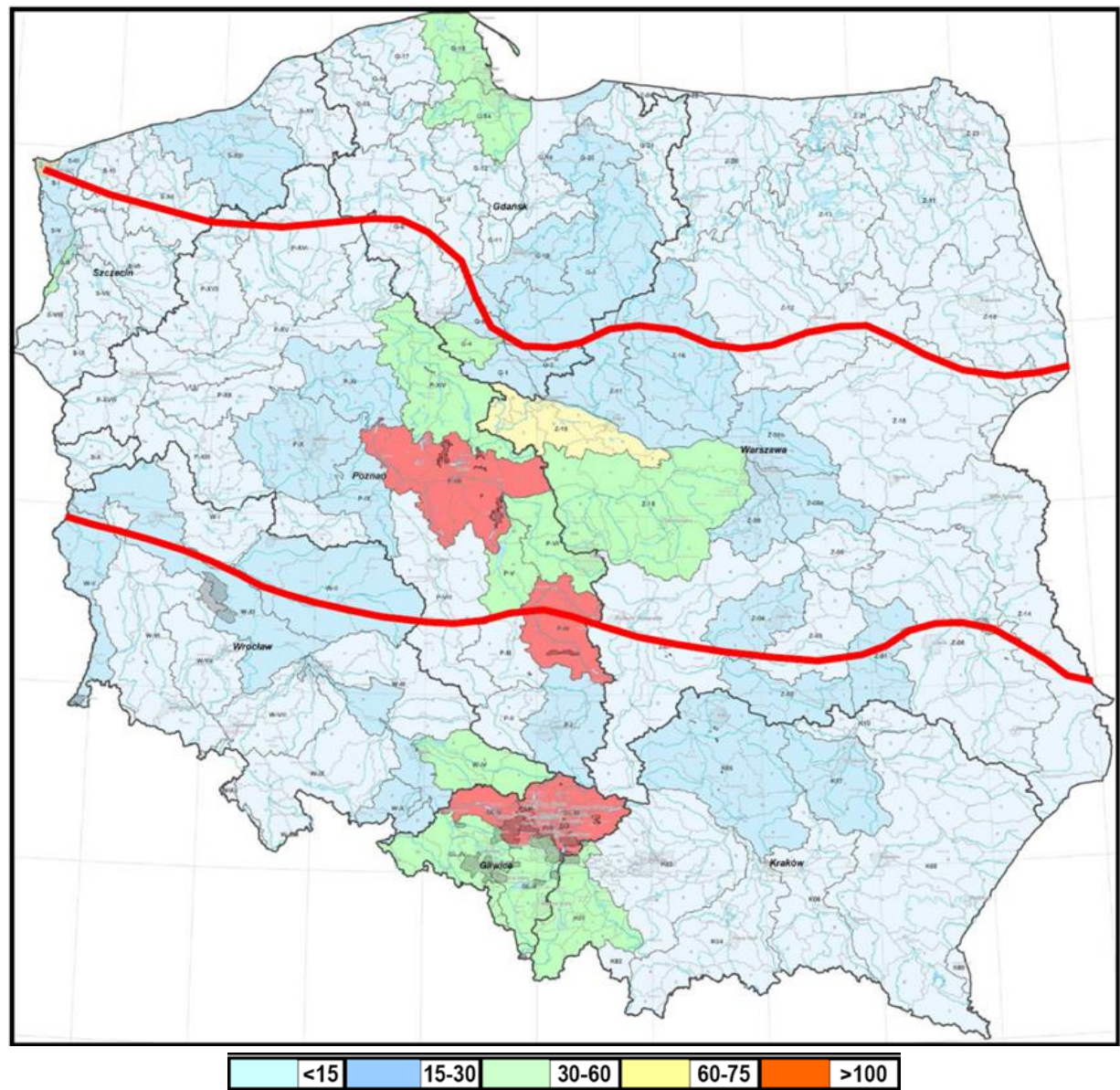

Ryc. 2. Stopień wzd (\%) wykorzystania zasobów dyspozycyjnych wód podziemnych w obszarach i jednostkach bilansowych

Objaśnienia: czerwona linia - granica obszaru środkowo-polskiego pasa suszy Źródło: Herbich i in. 2017, Herbich 2018

Interpretacja wysokiego stopnia zagospodarowania zasobów dyspozycyjnych ( $w z d>100 \%)$ w obszarach bilansowych, obejmujących odwodnienia górnicze i aglomeracje miejsko-przemysłowe, wymaga uzupełnienia komentarzem o sposobie wykorzystania pobranych tam wód podziemnych i o zmianach struktury bilansu hydrogeologicznego $\mathrm{w}$ regionalnym leju depresji (ryc. 2). Dwa z trzech takich obszarów występują w zasięgu środkowopolskiego pasa suszy 
o najniższych opadach atmosferycznych i wysokim, najwyższej częstotliwości występowania susz hydrologicznych w kraju (Stuczyński i in. 2007).

Drenaż górniczy jest poborem zwrotnym dla systemu hydrologicznego zlewni, gdyż pobrane wody są wprowadzane praktycznie w $100 \%$ jako zrzut oczyszczonych wód kopalnianych do rzek lub do wód podziemnych, w ramach rekultywacji wodnej odkrywkowych wyrobisk górniczych. Ponadto pobór wód podziemnych w leju depresji jest najczęściej znacznie wyższy od ich zasilania $w$ tym obszarze uwzględnianego na modelu matematycznym $w$ ramach ustalania zasobów dyspozycyjnych jednostki bilansowej, gdyż w leju depresji wzrasta infiltracja opadów atmosferycznych $w$ warunkach zmniejszonej ewapotranspiracji po osuszeniu podmokłości, zostaje wymuszona infiltracja z rzek i jezior do wód podziemnych, a także zachodzi sczerpywanie zasobów statycznych odwadnianego systemu wodonośnego. Podobnie pobór wód podziemnych z dużych ujęć komunalnych jest zwracany w ilości $>75 \%$ do rzek jako oczyszczone ścieki, a bilans hydrogeologiczny w obszarze leja depresji ujęć zmienia się w kierunku wzrostu zasobów odnawialnych systemu wodonośnego.

Ocena aktualnego stanu możliwych do zagospodarowania rezerw zasobów wód podziemnych jednostki bilansowej wymaga zatem przeprowadzenia jednolitego bilansu wodnogospodarczego zlewni, uwzględniającego m.in. wpływ zwrotu pobranych wód podziemnych na istotny wzrost przepływu rzek w strefie stanów niskich - powyżej wymaganego nienaruszalnego przepływu hydrobiologicznego (Herbich i in. 2013).

Intensywny pobór wód podziemnych do nawadniania upraw rolnych w okresie głębokiej suszy hydrologicznej powinien być prowadzony ze studni ujmującej poziom wodonośny o możliwie niskim stopniu zagrożenia spadkiem retencji, a tym samym spadkiem jej wydajności - w wyniku okresowego braku zasilania infiltracją efektywną opadów. Jednocześnie, po częściowym sczerpaniu zasobów statycznych wód podziemnych intensywnym poborem podczas suszy, ujęty poziom wodonośny powinien mieć hydrodynamicznie uwarunkowaną możliwość wydatnej odbudowy jego retencji infiltracją opadów w okresach występowania nadwyżki bilansu klimatycznego w określonym cyklu lat hydrologicznych.

W okresie suszy hydrologicznej następuje pogłębienie stanów niskich wody w rzekach do strefy przepływu hydrobiologicznie nienaruszalnego (skrajnie - aż do zaniku przepływu mniejszych rzek w ich górnym biegu), co praktycznie uniemożliwia efektywny pobór wód powierzchniowych do nawadniania upraw rolnych. W płytkich studniach kopanych następuje spadek lustra wody aż do jej wyschnięcia, natomiast w studniach wierconych ujmujących wody gruntowe dochodzi do znaczącego spadku ich wydajności w wyniku istotnego obniżenia możliwej do wytworzenia depresji eksploatacyjnej nad pompą. Natomiast hydrauliczne warunki eksploatacji studni wierconej, ujmującej poziom wodonośny o zwierciadle napiętym lub o poziom swobodny o dużej miąższości - nie ulegają istotnym zmianom w okresie suszy (ryc. 3).

Najkorzystniejsze hydrodynamicznie warunki dla ujmowania wód podziemnych w celu intensywnego poboru do nawadniania upraw rolnych podczas głębokiej suszy hydrologicznej i niżówki hydrogeologicznej spełnia główny użytkowy poziom wodonośny o zwierciadle napiętym, zasilany pośrednio stabilnym przesączaniem z poziomów wyżej ległych (typ NP - niezupełnie napięty i NS - niezupełnie swobodny). 


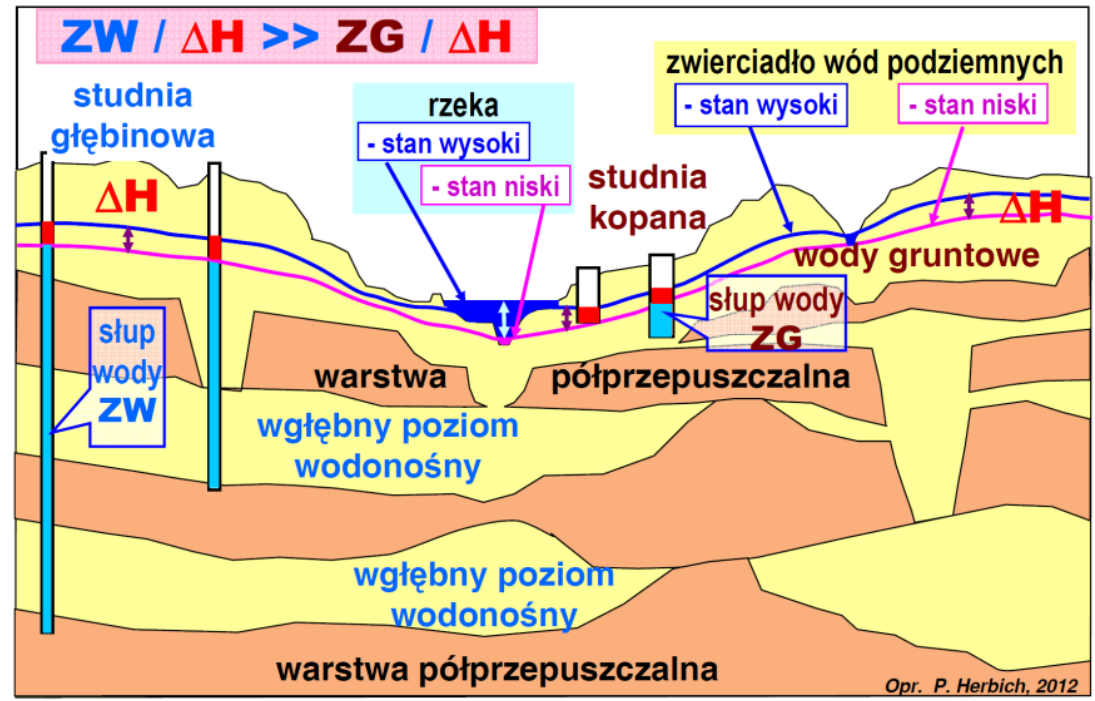

Ryc. 3. Porównanie wpływu spadku $\Delta \mathrm{H}$ lustra wody na słup wody w studniach ujmujących płytkie poziomy gruntowe $(\mathrm{G})$ i poziomy wgłębne $(\mathrm{W})$

Objaśnienia: $\Delta \mathrm{H}$ - obniżenie zwierciadła wody w studni; $\mathrm{Z}$ - słup wody w studni ujmującej: ZW poziom wgłębny, ZG wody gruntowe

Źródło: Herbich 2015

Najmniej korzystne warunki występują w poziomie wodonośnym typu S o miąższości mniejszej niż $10 \mathrm{~m}$, zwierciadle swobodnym i stanie retencji silnie reagującym na brak zasilania w roku skrajnie suchym (ryc. 4). Zrównoważony bilansowo intensywny pobór z naporowego poziomu wodonośnego typu NL (poziom wodonośny napięty z dopływem lateralnym) jest wprawdzie niewrażliwy na wpływ suszy hydrologicznej lecz przeważnie angażuje obszar zasilania ujęcia znacznie przekraczający nawadniany areał upraw rolnych przez okres dłuższy niż 5 lat.

Analiza hydrogeostrukturalnych i hydrodynamicznych warunków ujmowania wód podziemnych jest prowadzona z wykorzystaniem następujących warstw informacyjnych bazy danych GIS Mapy Hydrogeologicznej Polski w skali 1:50 000 (MHP):

- $\quad$ zapis symbolu jednostki hydrogeologicznej (podaje on użytkowe poziomy wodonośne UPW występujące w danej jednostce ze wskazaniem głównego użytkowego poziomu wodonośnego GUPW, jego pozycji w profilu pionowym i stopnia izolacji GUPW od powierzchni terenu: stopień a - brak izolacji, b - słaba izolacja, c - izolacja dobra oraz ab, ba, bc i cb - stopnie pośrednie);

- potencjalna wydajność typowej studni wierconej Qpot ujmującej GUWP (uwzględniana w przedziałach: 5-10, 10-30, 30-50, 50-70, 70-120 $\mathrm{m}^{3} / \mathrm{h}$ );

- przekroje hydrogeologiczne (ukazujące hydrostrukturalne i hydrodynamiczne warunki występowania GUPW i PPW w jednostce hydrogeologicznej);

- wskaźnik infiltracji efektywnej opadów SZO (PPW, w jednostce $\mathrm{mm} / \mathrm{r}$ ) do pierwszego poziomu wodonośnego, uwzględniany procedurze ustalania stopnia wrażliwości PPW na zanieczyszczenia z powierzchni terenu. 
Optymalizacja poboru wód podziemnych do nawadniania użytków rolnych w okresie suszy

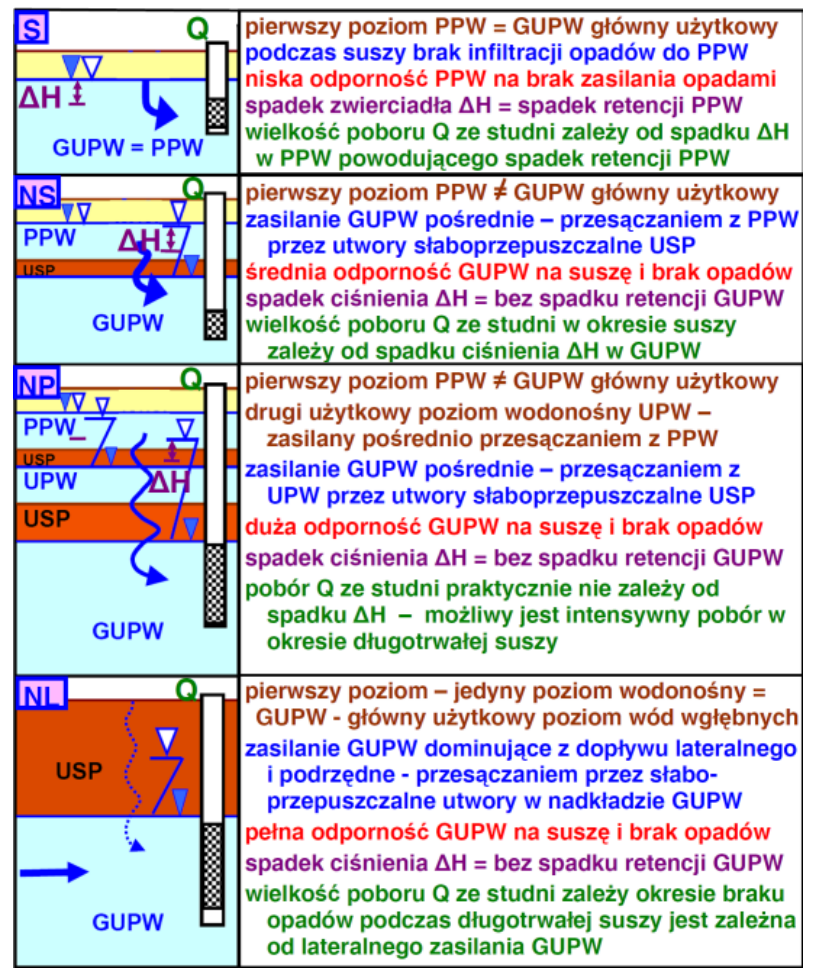

Ryc. 4. Charakterystyka hydrogeologiczna warunków zasilania poziomów wodonośnych ujmowanych do nawadniania upraw rolnych w okresie długotrwałej suszy hydrologicznej i niżówki hydrogeologicznej

Objaśnienia: typ hydrodynamiczny ujętego poziomu wodonośnego: S - swobodny,

$\mathrm{NS}$ - niezupełnie swobodny, NP - niezupełnie napięty, NL - napięty z dopływem lateralnym

\section{Źródło: Herbich 2015}

Średnia wieloletnia odnawialność zasobów SZO(GUPW) [mm/r] wytypowanego do ujmowania na cele nawodnieniowe GUPW jest określana z wykorzystaniem wskaźnika infiltracji efektywnej opadów do pierwszego poziomu wodonośnego SZO(PPW) (Rodzoch 2008) oraz stopnia współczynnika redukcji $W r$, zależnego od stopnia izolacji GUPW (tab. 1).

Tab. 1. Wartość współczynnika redukcyjnego $\mathbf{W r}$ przyjęta do obliczeń wskaźnika średniej wieloletniej odnawialności SZO(GUPW) głównego użytkowego poziomu wodonośnego (GUPW):

$\mathbf{S Z O}(\mathbf{G U P W})=\boldsymbol{W} \boldsymbol{r} \times \mathbf{S Z O}(\mathbf{P P W}) \mathrm{w}$ warunkach określonej odnawialności zasobów wód podziemnych pierwszego poziomu wodonośnego PPW

\begin{tabular}{|c|c|c|c|c|c|c|c|}
\hline \multirow{3}{*}{$\begin{array}{l}\text { Typ hydro- } \\
\text { dynamiczny } \\
\text { GUPW }\end{array}$} & \multirow{3}{*}{$\begin{array}{c}\text { Stopień } \\
\text { izolacji GUPW } \\
\text { wg MHP }\end{array}$} & \multirow{3}{*}{$\begin{array}{c}W r \\
{[-]}\end{array}$} & \multicolumn{5}{|c|}{ SZO(GUPW) $[\mathrm{mm} / \mathbf{r}]$} \\
\hline & & & \multicolumn{5}{|c|}{$S Z O(P P W)[\mathrm{mm} / \mathrm{r}]$} \\
\hline & & & 50 & 100 & 150 & 200 & 250 \\
\hline $\mathrm{S}$ & $\mathrm{a}$ & 1 & 50 & 100 & 150 & 200 & 250 \\
\hline NS & $a b$ & $0,9-0,8$ & $45-40$ & $90-80$ & $135-120$ & $180-160$ & $225-200$ \\
\hline NP & $\mathrm{ba}, \mathrm{b}$ & $0,7-0,5$ & $35-25$ & $70-50$ & $105-75$ & $140-100$ & $175-125$ \\
\hline $\mathrm{N}$ & $\mathrm{cb}, \mathrm{c}$ & $0,4-0,2$ & $20-10$ & $40-20$ & $60-30$ & $80-40$ & $100-50$ \\
\hline
\end{tabular}

Objaśnienia: stopień izolacji GUPW od powierzchni terenu: a - brak izolacji, $\mathrm{b}$ - słaba izolacja, $\mathrm{c}$ - dobra izolacja oraz stopnie pośrednie: ab i cb; pozostałe objaśnienia - patrz ryc. 4

Źródło: w oparciu o materiały Państwowej Służby Hydrogeologicznej z lat 2015-2017. 


\section{Analiza wyników}

W wyniku przeprowadzonych obliczeń ustalone zostały następujące charakterystyki optymalnych warunków poboru wód podziemnych do nawadniania upraw rolnych w okresie suszy (tab. $2,3,4,5$; ryc. 5$)$ :

- powierzchnia obszaru PNS (ha), na którym możliwe jest pokrycie niedoborów wodnych upraw rolnych w okresie suszy poborem z pojedynczej studni o wydajności Qpot $\left(\mathrm{m}^{3} / \mathrm{h}\right)$;

- czas TOR (lata) potrzebny na odbudowę stanu retencji ujętego poziomu wodonośnego W warunkach średniej wieloletniej odnawialności jego zasobów SZO $(\mathrm{mm} / \mathrm{r})$;

- powierzchnia obszaru POR (ha), na której w okresie 5. lat odnawialność zasobów głównego użytkowego poziomu wodonośnego SZO(GUPW) zrównoważy pobór wód podziemnych, prowadzony dla stałego nawadniania upraw ziemniaka późnego w sezonach wegetacyjnych jednego roku skrajnie suchego $(\mathrm{NW}=\mathrm{p} 20 \%)$, dwóch lat umiarkowanie suchych $(\mathrm{NW}=\mathrm{p} 50 \%)$ i dwóch lat co najmniej średnich ( $\mathrm{NW}=0,3 \mathrm{p} 50 \%)$.

Tab. 2. Przykład obliczeń parametrów charakteryzujących warunki i możliwości nawadniania pokrywającego niedobory wodne upraw rolnych w roku suchym

\begin{tabular}{|c|c|c|c|c|}
\hline Parametr & Symbol & $\begin{array}{c}\text { Przykładowa } \\
\text { wartość }\end{array}$ & Miano & $\begin{array}{c}\text { Źródło danych / } \\
\text { formula obliczeniowa }\end{array}$ \\
\hline \multirow{2}{*}{$\begin{array}{l}\text { sezonowy (w okresie wegetacyjnym) niedobór wody } \\
\text { w roku suchym o prawdopodobieństwie wystąpienia } \\
p=20 \%\end{array}$} & \multirow{2}{*}{ NWs $(20)$} & 240 & $\mathrm{~mm} / \mathrm{sezon}$ & Ostrowski i in. 2008 \\
\hline & & 2400 & $\mathrm{~m}^{3} /$ sezon $\times$ ha & Ostrowski i in. 2008 \\
\hline liczba dni w sezonie $\mathrm{z}$ nawadnianiem upraw & ts & 90 & doby & założenie \\
\hline efektywny czas nawadniania upraw w ciągu doby & td & 10 & $\mathrm{~h}$ (godziny) & założenie \\
\hline średni dobowy niedobór wody upraw w sezonie & NWtds & 27 & $\mathrm{~m}^{3} / 24 \mathrm{~h} \times 1 \mathrm{ha}$ & NWts=NWs/ts \\
\hline $\begin{array}{l}\text { moduł średniej wieloletniej odnawialności zasobów } \\
\text { PPW }\end{array}$ & $\mathrm{SZO}(\mathrm{PPW})$ & 100 & $\mathrm{~mm} / \mathrm{r}$ & Baza danych GIS MHP \\
\hline $\begin{array}{l}\text { współczynnik redukcyjny dla odnawialności } \\
\text { zasobów GUPW }\end{array}$ & $\mathrm{Wr}$ & 0,6 & - & założenie \\
\hline $\begin{array}{l}\text { moduł średniej wieloletniej odnawialności zasobów } \\
\text { GUPW }\end{array}$ & SZO(GUPW) & 60 & $\mathrm{~mm} / \mathrm{r}$ & $\begin{array}{l}\mathrm{SZO}(\mathrm{GUPW})= \\
\mathrm{Wr} \times \mathrm{SZO}(\mathrm{PPW})\end{array}$ \\
\hline $\begin{array}{l}\text { czas odbudowy retencji ujętego poziomu } \\
\text { wodonośnego }\end{array}$ & TOR & 4,0 & lata & TOR=NWs/SZO(GUPW) \\
\hline średnia wydajność potencjalna studni typowej & Qpot & 40 & $\mathrm{~m}^{3} / \mathrm{h}$ & Baza danych GIS MHP \\
\hline powierzchnia nawadniana przez 1. studnię typową & PNS & 15 & ha & $\mathrm{PNS}=\mathrm{Qpot} \times \mathrm{td} / \mathrm{NWtds}$ \\
\hline
\end{tabular}

Źródło: w oparciu o materiały Państwowej Służby Hydrogeologicznej z lat 2015-2017.

Zależnie od warunków hydrogeologicznych i rodzaju gleb, pobór z pojedynczej studni o wydajności potencjalnej Qpot $\geq 40 \mathrm{~m}^{3} / \mathrm{h}$ w okresie głębokiej suszy hydrologicznej o prawdopodobieństwie $20 \%$ (raz na 5 lat) może pokryć (tab. 3):

- wysokie niedobory wody upraw rolnych (NWs20 $\geq 180 \mathrm{~mm} / \mathrm{sezon})$ na powierzchni $\mathrm{PNS}=$ 10-60 ha;

- średnie niedobory $(120<\mathrm{NWs} 20<180 \mathrm{~mm} / \mathrm{sezon})$ na powierzchni PNS=20-90 ha;

- niskie niedobory $(\mathrm{NW} \leq 120 \mathrm{~mm} / \mathrm{sezon})$ na powierzchni PNS=30-140 ha.

Czas TOR odbudowy retencji zasobów ujętego poziomu wodonośnego, czerpanych w obszarze PNS poborem nawodnieniowym Qpot dla pokrycia niedoboru NW w roku skrajnie suchym (występującym raz na pięć lat), wyniesie nie więcej niż 5 lat, gdy średnia wieloletnia odnawialność zasobów ujętego poziomu będzie wynosiła SZO $>50 \mathrm{~mm} / \mathrm{r}$. Przykład obliczeń parametrów charakteryzujących warunki i możliwości nawadniania pokrywającego niedobory wodne upraw rolnych $w$ roku suchym podany jest $w$ tab. 2 , zaś wyniki - w tab. 3 i 4 i na ryc. 5. 
Optymalizacja poboru wód podziemnych do nawadniania użytków rolnych w okresie suszy

Tab. 3. Powierzchnia PNS [ha] upraw rolnych nawadnianych przez 1. studnię typową o wydajności potencjalnej Qpot $\left[\mathrm{m}^{3} / \mathrm{h}\right]$ w sezonie wegetacyjnym na pokrycie niedoboru wody NW [mm/sezon] podczas suszy występującej raz na 5 lat (prawdopodobieństwo wystąpienia $\mathrm{p}=20 \%$ )

\begin{tabular}{|c|c|c|c|c|c|}
\hline NW & $\mathrm{mm} / \mathrm{sezon}$ & \multicolumn{5}{|c|}{220} \\
\hline Qpot & $\mathrm{m}^{3} / \mathrm{h}$ & 40 & 60 & 80 & 120 \\
\hline PNS & ha & 10 & 30 & 40 & 30 \\
\hline NW & $\mathrm{mm} / \mathrm{sezon}$ & \multicolumn{5}{|c|}{180} \\
\hline Qpot & $\mathrm{m}^{3} / \mathrm{h}$ & 40 & 60 & 85 & 120 \\
\hline PNS & ha & 20 & 30 & 40 & 60 \\
\hline NW & $\mathrm{mm} / \mathrm{sezon}$ & \multicolumn{5}{|c|}{140} \\
\hline Qpot & $\mathrm{m}^{3} / \mathrm{h}$ & 40 & 60 & 85 & 120 \\
\hline PNS & ha & 30 & 40 & 50 & 80 \\
\hline NW & $\mathrm{mm} / \mathrm{sezon}$ & \multicolumn{5}{|c|}{120} \\
\hline Qpot & $\mathrm{m}^{3} / \mathrm{h}$ & 40 & 60 & 85 & 120 \\
\hline PNS & ha & 30 & 50 & 60 & 90 \\
\hline NW & $\mathrm{mm} / \mathrm{sezon}$ & \multicolumn{5}{|c|}{100} \\
\hline Qpot & $\mathrm{m}^{3} / \mathrm{h}$ & 40 & 60 & 85 & 120 \\
\hline PNS & ha & 40 & 50 & 80 & 110 \\
\hline NW & $\mathrm{mm} / \mathrm{sezon}$ & \multicolumn{5}{|c|}{80} \\
\hline Qpot & $\mathrm{m}^{3} / \mathrm{h}$ & 40 & 60 & 85 & 120 \\
\hline PNS & ha & 50 & 70 & 100 & 140 \\
\hline
\end{tabular}

Objaśnienia: w obliczeniach uwzględniano 10-cio godzinny czas trwania poboru Qpot w ciągu doby na potrzeby nawadniania w sezonie wegetacyjnym

Źródło: Herbich 2017.

Tab. 4. Wartości czasu odbudowy stanu retencji TOR w poziomie wodonośnym o średniej wieloletniej odnawialności zasobów SZO, ujętym przez studnię eksploatowaną na pokrycie niedoboru wody NW upraw rolnych w sezonie wegetacyjnym podczas suszy występującej raz na 5 lat $(\mathrm{p}=20 \%)$

\begin{tabular}{|c|c|c|c|c|c|c|c|}
\hline NW & $\mathrm{mm} / \mathrm{sezon}$ & \multicolumn{7}{|c|}{220} \\
\hline SZO & $\mathrm{mm} / \mathrm{r}$ & 20 & 40 & 50 & 60 & 90 & 120 \\
\hline TOR & lata & $\mathbf{1 0}$ & $\mathbf{6}$ & $\mathbf{5}$ & 4 & 3 & 2 \\
\hline NW & $\mathrm{mm} / \mathrm{sezon}$ & \multicolumn{7}{|c|}{180} \\
\hline SZO & $\mathrm{mm} / \mathrm{r}$ & 20 & 40 & 50 & 60 & 90 & 120 \\
\hline TOR & lata & $\mathbf{9}$ & $\mathbf{5}$ & 4 & 3 & 2 & 1 \\
\hline NW & $\mathrm{mm} / \mathrm{sezon}$ & \multicolumn{7}{|c|}{140} \\
\hline SZO & $\mathrm{mm} / \mathrm{r}$ & 20 & 40 & 50 & 60 & 90 & 120 \\
\hline TOR & lata & $\mathbf{7}$ & 4 & 3 & 2 & 2 & 1 \\
\hline NW & $\mathrm{mm} / \mathrm{sezon}$ & \multicolumn{7}{|c|}{120} \\
\hline SZO & $\mathrm{mm} / \mathrm{r}$ & 20 & 40 & 50 & 60 & 90 & 120 \\
\hline TOR & lata & $\mathbf{6}$ & 3 & 2 & 2 & 1 & 1 \\
\hline NW & $\mathrm{mm} / \mathrm{sezon}$ & \multicolumn{7}{|c|}{100} \\
\hline SZO & $\mathrm{mm} / \mathrm{r}$ & 20 & 40 & 50 & 60 & 90 & 120 \\
\hline TOR & lata & $\mathbf{5}$ & 3 & 2 & 2 & 1 & 1 \\
\hline NW & $\mathrm{mm} / \mathrm{sezon}$ & \multicolumn{7}{|c|}{80} \\
\hline SZO & $\mathrm{mm} / \mathrm{r}$ & 20 & 40 & 50 & 60 & 90 & 120 \\
\hline TOR & lata & 4 & 2 & 2 & 1 & 1 & 1 \\
\hline
\end{tabular}

Objaśnienia: wyboldowano czas odbudowy TOR $\geq 5$ lat

Źródło: Herbich 2017. 
W 5-leciu, obejmującym jeden rok skrajnie suchy $(\mathrm{NWp}=20 \%)$, dwa lata umiarkowanie suche $(\mathrm{NWp}=50 \%)$ i dwa lata co najmniej średnie (NW0,3p50\%), stały - systematyczny pobór wód podziemnych niezbędny do nawadniania 10 ha upraw rolnych, w warunkach niskiej wartości $\mathrm{SZO}(\mathrm{GUPW})=50 \mathrm{~mm} /$ rok średniego wieloletniego zasilania ujętego poziomu wodonośnego jest zbilansowany na obszarze POR o powierzchni od 7 ha do 32 ha, zależnie od typu gleb i regionu klimatycznego. W warunkach wysokiej wartości średniego wieloletniego zasilania $\mathrm{SZO}(\mathrm{GUPW})=150 \mathrm{~mm} /$ rok pobór taki jest zbilansowany na obszarze $\mathrm{POR}<10$ ha nawadnianych upraw rolnych prowadzonych praktycznie na każdym typie gleb we wszystkich regionach klimatycznych (tab. 5).

Tab. 5. Powierzchnia obszaru POR [ha] zapewniająca odbudowę retencji w poziomie wodonośnym w warunkach średniego wieloletniego zasilania SZO (A: SZO=50 $\mathbf{~ m m} / \mathbf{r}, \mathbf{B}: \mathbf{S Z O}=\mathbf{1 5 0} \mathbf{~ m m} / \mathbf{r})$, w warunkach poboru wody do nawodnień upraw ziemniaka późnego prowadzonych w sezonie wegetacyjnym na areale 10 ha, pokrywających niedobory wody NW upraw w 5-letnim cyklu hydrologicznym, obejmującym jeden rok

skrajnie suchy (NWp20\%), dwa lata przeciętnie suche (NWp50\%) i 2 lata normalne (NW 0,3P50\%)

\begin{tabular}{|l|r|r|r|r|r|r|r|r|}
\hline \multirow{3}{*}{ Region } & \multicolumn{4}{|c|}{ A: SZO=50 mm/r } & \multicolumn{4}{c|}{ B: SZO=150 mm/r } \\
\cline { 2 - 10 } & \multicolumn{4}{|c|}{ Typ gleby } & \multicolumn{4}{c|}{ Typ gleby } \\
\cline { 2 - 10 } & ciężka & średnia & \multicolumn{1}{|c|}{ lekka } & b.lekka & ciężka & średnia & \multicolumn{1}{c|}{ lekka } & b.lekka \\
\hline Zachodnipomorski & 17,81 & 19,80 & 23,42 & 31,97 & 5,94 & 6,60 & 7,81 & 10,66 \\
\hline Pomorze & 11,09 & 12,63 & 15,65 & 23,13 & 3,70 & 4,21 & 5,22 & 7,71 \\
\hline Warmińsko-Mazurski & 7,35 & 8,30 & 10,29 & 16,34 & 2,45 & 2,77 & 3,43 & 5,45 \\
\hline Podlasie & 6,60 & 7,66 & 10,00 & 16,55 & 2,20 & 2,55 & 3,33 & 5,52 \\
\hline Kujawy & 15,01 & 16,91 & 20,12 & 28,43 & 5,00 & 5,64 & 6,71 & 9,48 \\
\hline Ziemia Lubuska & 18,37 & 20,26 & 23,57 & 31,39 & 6,12 & 6,75 & 7,86 & 10,46 \\
\hline Wielkopolska & 20,43 & 22,34 & 25,72 & 33,62 & 6,81 & 7,45 & 8,57 & 11,21 \\
\hline Województwo Łódzkie & 14,28 & 16,06 & 19,40 & 27,80 & 4,76 & 5,35 & 6,47 & 9,27 \\
\hline Mazowsze & 16,38 & 18,30 & 21,85 & 29,91 & 5,46 & 6,10 & 7,28 & 9,97 \\
\hline Polesie Lubelskie & 9,66 & 11,38 & 14,63 & 22,72 & 3,22 & 3,79 & 4,88 & 7,57 \\
\hline Dolny Śląsk & 11,91 & 13,58 & 16,82 & 24,65 & 3,97 & 4,53 & 5,61 & 8,22 \\
\hline Opolszczyzna & 10,83 & 12,21 & 15,23 & 22,91 & 3,61 & 4,07 & 5,08 & 7,64 \\
\hline Małopolska & 5,69 & 6,90 & 9,43 & 15,85 & 1,90 & 2,30 & 3,14 & 5,28 \\
\hline Podkarpackie & 7,68 & 8,74 & 11,29 & 17,89 & 2,56 & 2,91 & 3,76 & 5,96 \\
\hline
\end{tabular}

Objaśnienia: kolorem zaznaczono obszary POR o powierzchni przekraczającej nawadniany areał 10 ha upraw (żółtym: 10 ha<POR<20 ha, różowym: POR>20 ha)

Źródło: Herbich 2017.

Warunki hydrogeologiczne ujmowania wód podziemnych z głównego użytkowego poziomu wodonośnego w obszarze arkuszy Mapy Hydrogeologicznej Polski w skali 1:50 000 - nr 487 „Legionowo” i nr 626 „Lutomiersk”, prowadzonego do nawodnienia potencjalnych terenów uprawy ziemniaka późnego, pokrywającego niedobory wodne w okresie suszy występującej raz na 5 lat, pokazane są na ryc. 5. 
Optymalizacja poboru wód podziemnych do nawadniania użytków rolnych w okresie suszy

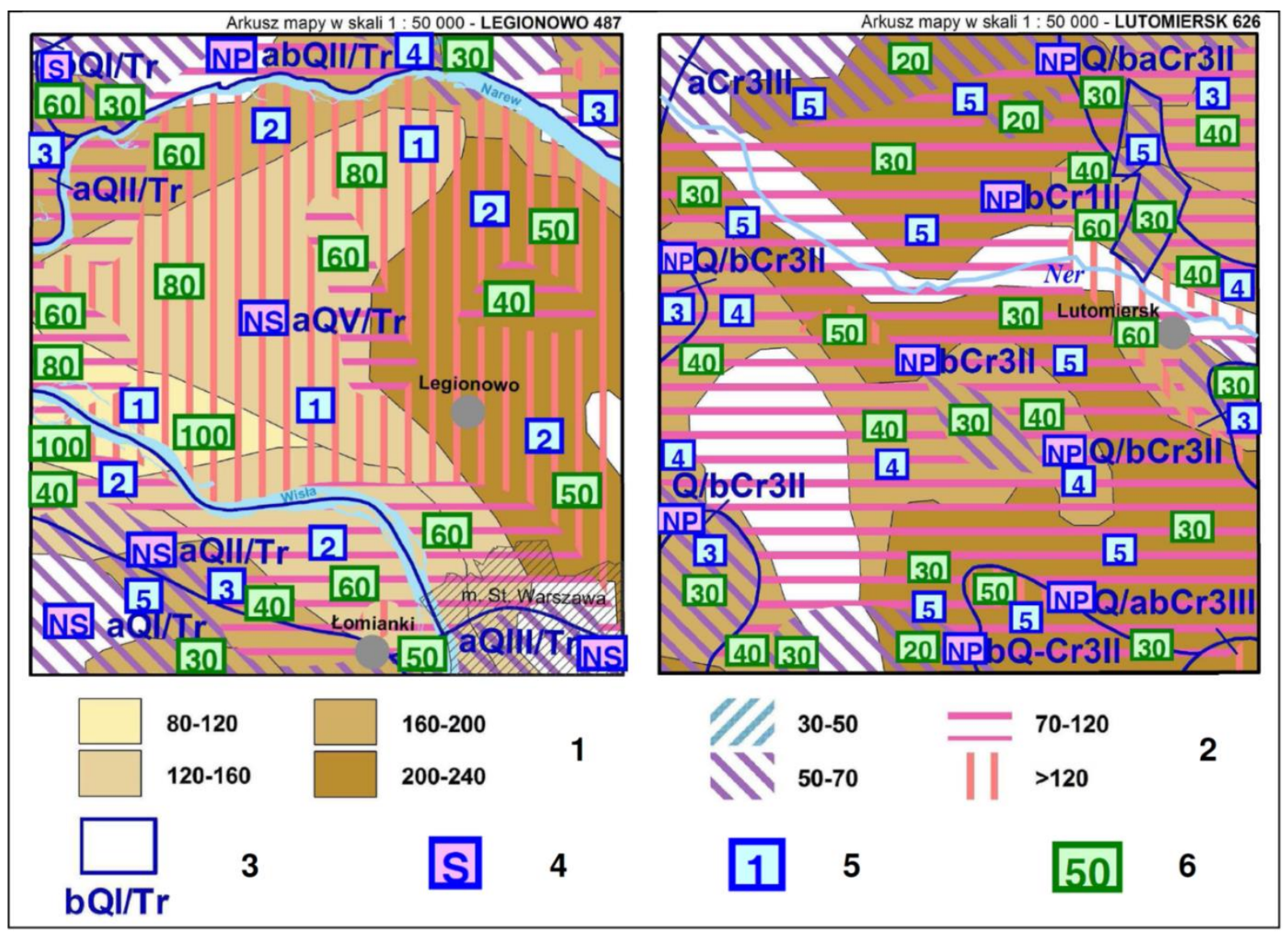

Ryc. 5. Warunki hydrogeologiczne ujmowania wód podziemnych z użytkowych poziomów wodonośnych na łagodzenie skutków suszy w obszarze arkuszy MHP: Legionowo (487) i Lutomiersk (626) do nawadniania terenów potencjalnych upraw ziemniaka późnego, pokrywających niedobory wodne w okresie suszy występującej raz na 5 lat

Objaśnienia:

1 - niedobory wodne NW upraw ziemniaka w okresie suszy występującej raz na 5 lat (mm/sezon),

2 - wydajność potencjalna studni typowej Qpot $\left(\mathrm{m}^{3} / \mathrm{h}\right)$,

3 - zapis symbolu jednostki hydrogeologicznej głównego użytkowego poziomu wodonośnego wydzielonej na MHP w skali 1:50 000 (Instrukcja 1999),

4 - typ hydrodynamiczny ujętego poziomu wodonośnego (patrz ryc. 4 , tab. 1),

5 - czas odbudowy retencji wód podziemnych GUPW w obszarze spływu do studni TOR (lata),

6 - powierzchnia upraw możliwa do nawodnienia przez jedną studnię o typowej wydajności potencjalnej PNS (ha)

Źródło: Herbich i in. 2018, Herbich 2019

Przeprowadzone obliczenia wykazały, że w obszarze objętym tymi arkuszami MHP, pobór z pojedynczej studni może pokryć niedobory wodne na areale od 30 ha do 100 ha, zaś czas odbudowy stanu retencji głównego poziomu wodonośnego nie będzie przekraczał 5 lat. 


\section{Wnioski}

Aktualny bilans wodnogospodarczy wód podziemnych kraju wykazuje niski stopień (średnio ok. 20\%) wykorzystania ich zasobów dyspozycyjnych w jednostkach bilansowych oraz wysoki stopień (ponad 75\%) zwrotu pobranych wód do systemu hydrologicznego w postaci oczyszczonych ścieków komunalnych i wód kopalnianych.

Znaczne i powszechnie występujące rezerwy zasobów dyspozycyjnych wód podziemnych mogą być podstawowym źródłem dla pokrywania niedoborów wodnych upraw rolnych w okresie głębokiej suszy hydrologicznej o prawdopodobieństwie wystapienia raz na 5 lat, jak i w sposób ciągły, zapewniający uzyskiwanie wysokich plonów.

Pobór wód podziemnych dla nawadniania upraw rolnych jest ekonomicznie i technicznie uzasadniony ze względu na powszechne występowanie użytkowych poziomów wodonośnych, zapewniających odpowiednią wydajność studni, co jest istotne zwłaszcza w warunkach braku dostępności do zasobów wód powierzchniowych w latach suchych.

Stan retencji poziomów wodonośnych, okresowo obniżany w wyniku intensywnego i skoncentrowanego poboru wód podziemnych na cele nawodnieniowe w latach suchych, jest odbudowywany w latach o normalnej i wysokiej sumie opadów na obszarze najczęściej nie przekraczającym dwukrotnej powierzchni nawadnianych upraw.

Najkorzystniejsze warunki hydrogeologiczne dla okresowego intensywnego poboru wód podziemnych do nawodnień rolnych w latach posusznych występują w wielopoziomowych systemach wodonośnych o znacznej miąższości, gdy ujmowany jest poziom wodonośny o zwierciadle napiętym, zasilany stabilnym przesączaniem z poziomów wyżej ległych.

Zaproponowana metodyka obliczeń jest podstawą dla wstępnej oceny możliwości wykorzystania rezerw dyspozycyjnych zasobów wód podziemnych do nawadniania upraw rolnych w konkretnej lokalizacji wystąpienia takich potrzeb.

Dokonanie w pełni miarodajnej oceny możliwości wykorzystania wód podziemnych do nawadniania rolniczego o konkretnej lokalizacji obiektu, jego powierzchni i rodzaju uprawy, jest możliwe dopiero na etapie sporządzania projektu prac geologicznych na wykonanie dokumentacji hydrogeologicznej, ustalającej zasoby eksploatacyjne ujęcia wód podziemnych na potrzeby uzupełniania niedoborów wodnych upraw rolnych.

W dokumentacji powinny być uwzględnione wszelkie ograniczenia dla planowanego poboru wód podziemnych, wynikające z wymogów ustanowionych dla obszarów ochronnych i utrzymania określonego stanu jednolitych części wód podziemnych, z obowiązku zachowania nabytych praw do korzystania z wód przez innych użytkowników wód podziemnych, utrzymania określonego stanu retencji ujętego poziomu wodonośnego oraz spełnienia lokalnych priorytetów w dostępie do zagospodarowania rezerw zasobów wodnych zlewni.

Wniosek o udzielenie pozwolenia wodnoprawnego na pobór wód podziemnych do nawadniania upraw rolnych powinien również wykazać brak uzasadnionych ekonomicznie, hydrologicznie i technicznie warunków dla odpowiedniego poboru wód powierzchniowych oraz powinien wskazać na istnienie rezerw zasobów wód podziemnych w danej jednostce bilansowej, możliwych do zagospodarowania z zachowaniem wymienionych wyżej ograniczeń dla poboru wód. 
Optymalizacja poboru wód podziemnych do nawadniania użytków rolnych w okresie suszy

\section{Bibliografia}

Baza GIS MHP, https://www.pgi.gov.pl/psh/dane-hydrogeologiczne-psh/947-bazy-danychhydrogeologiczne/8888-dane-hydrogeologiczne-mhp.html (dostęp: 15.08.2021).

Herbich P., Mordzonek P., Przytuła E., 2017, Stopień wykorzystania dostępnych do zagospodarowania zasobów wód podziemnych w Polsce,PIG Warszawa 2017, https://www.pgi. gov.pl/psh/materialy-informacyjne-psh/stan-srodowiskowy-wod-podziemnych.html (dostęp: 15.08.2021).

Herbich P. i in., 2018, Określenie możliwości poboru wód podziemnych na cele nawodnień rol-niczych oraz okresowego łagodzenia skutków suszy gospodarczej, Zadania Państwowej Stużby Hydrogeologicznej w 2017 r. Synteza, Warszawa, marzec 2018 r., https://www.pgi.gov.pl/psh/psh-2/najnowsze-publikacje/5951-synteza-psh-2017.html (dostęp: 15.08.2021).

Herbich P., 2019, Ocena możliwości wykorzystania rezerw zasobów dyspozycyjnych wód podziemnych do tagodzenia suszy w rolnictwie, Biuletyn PIG nr 475.

Instrukcja opracowania i komputerowej edycji Mapy Hydrogeologicznej Polski w skali 1:50 000, PIG, Warszawa, 1999.

Ostrowski J., Łabędzki L., Kowalik W., Kanecka-Geszke E., Kasperska-Wołowicz W., Smarzyńska K., Tusiński E., 2008, Atlas niedoborów wodnych roślin uprawnych i użytków zielonych $w$ Polsce, Wyd. IMUZ, Falenty.

Rodzoch A., 2008, Przegladowa mapa wskaźnika odnawialności zasobów pierwszego poziomu wodonośnego, HYDROEKO Warszawa, Arch. MHP w PIG-PIB, Warszawa.

Stuczyński Tomasz i in., 2007, Przyrodnicze uwarunkowania produkcji rolniczej w Polsce, Studia i raporty IUNG - PIB, zeszyt 7.

Ustawa z dnia 20 lipca 2017 r. Prawo wodne (Dz.U. z 2001 r., nr 115, poz. 1229; Dz.U. z 2017 r., poz. 1566). 